Dialectologia 22 (2019), 101-114.

ISSN: 2013-2247

Received 23 March 2017.

Accepted 16 July 2017.

\title{
FUTURE I TENSE FORM IN THE PRIZREN-TIMOK DIALECT OF SERBIAN
}

\author{
Aleksandar NovaKović \& Violeta StoJıčıć \\ University of Niš* \\ aleksandar.novakovic@filfak.ni.ac.rs / violeta.stojicic@filfak.ni.ac.rs
}

\begin{abstract}
This paper examines the impact of Serbian language teaching on the use of the normative Future I tense form in ordinary language and on the use of futuroid, a dialectal Future I tense form, which is the construction consisting of the conjunction $\partial a$ and the present tense, used in the Prizren-Timok dialect of southeastern Serbia. The research conducted has indicated that the adult users of the dialect shall be more liable to use the dialectal form in the language than the young learners who are still in the process of grammar learning. The connection between the Serbian language teaching and the use of the futuroid construction in the dialect has been investigated quantitatively by means of SPSS 20.0 software.
\end{abstract}

\section{Keywords}

Prizren-Timok dialect, future tense, futuroid, Serbian

\section{Resumen}

\section{LA FORMA DE FUTURO EN EL DIALECTO SERBIO DE PRIZREN-TIMOK}

Este artículo examina el impacto de la enseñanza del idioma serbio en el uso de la forma de futuro I normativa en el habla habitual y en el uso del futuroide, una forma dialectal de futuro, que es la construcción que consiste en la conjunción da y el tiempo de presente que se usa en el dialecto PrizrenTimok del sureste de Serbia. La investigación realizada ha indicado que los usuarios adultos del dialecto serán más propensos a usar la forma dialectal que los jóvenes estudiantes que aún están en proceso de aprendizaje de la gramática. La conexión entre la enseñanza del idioma serbio y el uso de la construcción del futuroide en el dialecto se ha investigado cuantitativamente mediante el software SPSS 20.0.

\footnotetext{
* University of Niš, Faculty of Philosophy, Ćirila i Metodija 2, Niš, Serbia.
} 
Palabras clave

dialecto Prizren-Timok, tiempo de futuro, futuroide, serbio

\section{Introduction}

The establishment of the Balkan language union has led to a significant interlinguistic influence and a larger number of common traits, known as Balkanisms, in grammar, syntax, lexis, etc. In the Serbian language community, the influence of the Balkan linguistic features progresses from the south/southeast towards the north/northeast area, bearing impact on a significant number of dialects (Radić 2011: 68). One may observe that the Prizren-Timok dialect is the most susceptible to the influence, much more than Kosovo-Resavian or Zeta-Sjenica dialects. Due to its specific features, the dialect of the southeastern area of Serbia is regarded as the most prominent phenomenon in Serbian dialectology (Ivić 1985: 110-123). One of the most prominent primary Balkanisms is the construction $\partial a+$ present which serves as the infinitive substitute in the formation of the Future I tense form (cf. Mutavdžić 2013). In a few dialects of the Serbian language one may notice a tendency of the speakers to habitually use the construction $\partial a+$ present, termed 'futuroid', instead of the infinitive in the formation of the Future I, even though the infinitive is the norm in the standard Serbian language. This substitution is mainly related to the influence of other languages in the Balkans, especially on the dialects in the area of south-eastern and central Serbia.

In this research, dialect shall be considered a regional variety of language, i.e. regional dialect. For the definition of dialect, we have referred to Meyerhoff (2006: 27), in which dialects are described as sub-varieties of a language which differ not only in pronunciation, but also on the basis of morpho-syntactic structures and/or how semantic relations are mapped into the syntax. The term Prizren-Timok dialect, which belongs to the eastern Shtokavian dialects, designates a geographical variety which is spoken in the south-eastern area of the Republic of Serbia. It is different in certain linguistic aspects from other dialects of the language; in this paper we are concerned with the difference between the Prizren-Timok dialect and the standard dialect observed in the formation of the Future I tense form. The feature of the Prizren-Timok 
dialect discussed here is not evaluated as an error but as a contrast found in comparison to the standard. We wish to investigate to what extent the sets of rules which operate in the dialect with regard to Future I are followed by young learners and by adults.

In the standard variety of Serbian, Future I is formed by the present tense clitic forms of the verb xmemu 'will' and the infinitive of the main verb. Table 1 contains clitic and non-clitic forms the auxiliary verb:

\begin{tabular}{|l|l|l|}
\hline person & clitic form & non-clitic form \\
\hline ја (I) & $\hbar y$ & xоћy \\
\hline ти (уои) & ћеш & хоћеш \\
\hline он, она, оно (he, she, it) & $\hbar е$ & хоће \\
\hline ми (ше) & ћемо & хоћемо \\
\hline ви (уои) & ћете & хоћете \\
\hline они, оне, она (they) & ће & хоће \\
\hline
\end{tabular}

Table 1 Clitic and non-clitic present tense forms of the auxiliary verb xmemu 'will'

To form the Future I tense, one needs to use the clitic forms, for example Они ће купити нов стан (lit. 'They will buy a new flat'). When the subject is omitted, the clitic is attached to the infinitive stem, e.g. Купиће нов стан. The dialectal form to be discussed in this research is a construction used as a substitute for the infinitive in the structure illustrated by Они ће купити нов стан. The dialectal infinitive substitute, which we shall refer to as futuroid, consists of the conjunction $\partial a$ and the present tense form of the main verb, e.g. Они ће да купе нов стан.

To date, there has been no investigation of the impact of mother tongue teaching on the use of structures prominent in a dialect in the dialectological literature in Serbian, nor has the influence of age ever been addressed. In our teaching practice, we have noticed that the Serbian language teaching has a significant role in promoting the standard form of the Future I in speech and writing. Generally speaking, the objectives of the teaching process in the Serbian classroom have always involved the preservance of the standard dialect, without any references to the acceptability or non-acceptability of other geographical or social variants of the language. This paper focuses on the effect Serbian teaching has at the level of primary education in an individual speaker's linguistic performance with regard to the Future I tense formation. 


\section{Theoretical considerations}

Brozović (1953: 13-18) deals with the semantic and stylistic features of the $\partial a+$ present construction as it is used with certain verbs, adjectives and nouns. In Brozović (1953: 13-18) it is stated that this is an interesting phenomenon in Serbian; namely, the philologist Moskovljević (in Brozović 1953: 13-18) claims that the infinitive and the $\partial a+$ present tense do not have the same implications. The distinction is based on the fact that the verb xmemu can be used as a content word [WANT], as in Cympa нећу да идем y школу (lit. 'Tomorrow I do not want to go to school'), and as an auxiliary verb in the Future I tense from, as in Cутра нећу ићи у школу (lit. 'Tomorrow I will not go to school') (Brozović 1953: 14).

Barjaktarević (1981: 328) argues that the loss of the infinitive in the future tense form can be ascribed to a foreign influence. Furthermore, in some of the sub-dialects of the Shtokavian dialect the conjunction $\partial a$ is often omitted, so that the construction which is often found in ordinary language use is $\hbar y+$ present tense. Interestingly, Stevanović (1986: 601) does not report on the use of the $\partial a+$ present construction with regard to the morphology and syntax of the future tense, but with regard to the use of the infinitive. He suggests that the infinitive should be used instead of the $\partial a+$ present construction in two cases: first, at the beginning of a sentence, such as in the question Хоћеш ли доћu? (lit. 'Will you come?'), and second, when the form of the verb xmemu is negative in the future tense structure, e.g. Heћy вume numu (lit. 'I will not drink anymore'). Discussing the norm in the Serbian language, Mrazović \& Vukadinović (1990: 145) maintain that the verb xmemu in its modal usage should be complemented by $\partial a+$ present, while in its auxiliary function in the future tense form it should be used with the infinitive. In her investigation of the dialects used in south-eastern Serbia, Topolinjska (1994: 153) describes four models of the formation of Future I, two of which even omit the conjunction $\partial a$, e.g. 1) ja ћу/хоћу/нећу да пишем, 2) ја ћу/хоћу/нећу пишем, 3) ja ће да пишем and 4) ja ће пишем.

In 2002, the Committee for the Standardization of the Serbian language in Decision No. 24 paid special attention to the relationship between the $\partial a$ construction 
and the infinitive. Considering the position wich the Board took on the future tense form, the decision indicates that the infinitive has an explicit priority over the $\partial a+$ present construction in the Future I tense formation within the standard and conventional language use. Accordingly, the literature has underlined that the $\partial a+$ present construction is predominately used in eastern dialects of Serbian as a Future I substitute (cf. Piper et al. 2005; Ćorić 2005). For instance, Ćorić (2005: 281) holds that it is a salient feature of south-eastern dialects, which has, however, started spreading to other dialects and sub-dialects of the language. He draws the attention to the fact that there is a tendency in the Balkans to abandon the overall usage of the infinitive. Simić (2009: 52) claims that it would be strange at least to reconsider accepting the idea that there exists a finite verb form consisting of two finite forms, such as $\hbar$ да дођем (lit. 'I will that I come'). For that reason, the construction belongs to the domain of the dialect and is not tolerated in the standard language as a norm. Miloradović (2015: 80-81) finds that the Prizren-Timok dialect is characterized by a gradual abandonment of the infinitive, especially in Future I, in which it is replaced by $\partial a+$ present, as already mentioned, in which the form he has almost acquired the status of a particle and has been used as a substitute form for all finite forms of the auxiliary xmemu ( $\hbar y, \hbar e m, \hbar e$, ћемо, ћете, ће).

In his discussion of futuroid, Simić (2009: 53) concludes that it has become rather frequent not only as a complement of modal verbs, but also as a regular Future I substitute. Simić (2009: 53) finds that it is habitually used in everyday conversational language in certain dialects; moreover, it is also identified in the writings of renowned Serbian writers, the language of which serves as a desirable model of standard language use. Simić (2009: 53) argues that this construction is documented in the novel Koreni by D. Ćosić, in which there are instances of Kosovo-Braničevo dialect, with 214 examples of standard Future I form and 74 examples of futuroid. Also, a similar study of the novel Vreme vlasti by D. Ćosić has suggested that futuroid is regularly used in sentences in which the speaker expresses doubt, insecurity, a wish or a reflective thought (e.g. Kad ću ja da se vratim? lit. When will I be back?) (Simić 2009: 53) 


\section{Futur I in the Serbian language classroom and the Prizren-Timok dialect}

The Serbian language and literature teaching in primary education has an important role in the dissemination of the standard language norm. Essentially, the objective of the teaching is to attain full language literacy on the basis of orthoepic and orthographic standards of the Serbian language, linguistic phenomena and concepts in lexis, morphology, syntax and stylistics, all of which are a platform for reading fluency and writing skills in the standard language use. It is believed that the decrease in the number of grammar classes in higher education initiates a prevalence of non-standard dialectal tense forms in everyday language use. Consequently, Serbian speakers shall habitually use the standard Future I form while taught in the Serbian language classroom, while the dialectal form shall be more commonly used as their language learning activities lapse. Therefore, this study is intended to indicate the extent to which the process of Balkanization operates in the Prizren-Timok dialect and in individual speakers in the domain of future tense formation.

As Janjic (2004: 408) explains, the Prizren-Timok dialect does not represent the ideal framework for an easy adoption of the principles of the standard language, in this case of the principles of Future I formation. Furthermore, we have noticed that the fewer the number of classes of Serbian per week in elementary or high school, the greater the influence of dialectal linguistic parameters in a non-standard dialect user. In our teaching practice, we have noticed that an average Serbian speaker in the PrizrenTimok dialect zone is often puzzled by the existence of the two modes of the formation of Future I - one accepted as a norm in the standard language and the other used in the dialect. The latter has become so prevalent on the entire Prizren-Timok dialect territory, that the norm has almost entirely fallen into disuse in both speech and writing. The matter of the fact is that the Prizren-Timok dialect users often fail to recall the norm in their adult years; they habitually accept and employ the dialectal futuroid even in the official communication.

In this vein, we hypothesize that the use of futuroid will be of higher frequency with adult dialect users than with young learners at school. In accordance with the subject of the research, we may identify the following research tasks: 
a) Study the frequency of usage of standard and dialectal Future I forms with elementary school learners within the Prizren-Timok dialect zone;

b) Study the frequency of usage of standard and dialectal Future I forms with adults within the Prizren-Timok dialect zone.

This research employs both quantitative and qualitative methods of data analysis. We have devised a questionnaire as an instrument for data collection, the English translation of which we provide as an Appendix I. In the tasks assigned there is no information which implies that any of the verb forms to be provided by the respondents should be standard or vernacular, or grammatically correct. The tasks, therefore, are not guided, so that the respondents rely entirely on their native speaker's intuition and a sense of naturalness in the language use. The data collected by the questionnaire were not intended to be assessed for grammatical correctness or acceptability from the point of view of the prestige dialect.

Task 1 comprises sentences in which a future tense form is to be provided in the blanks on the basis of the verbs offered in the brackets in present tense form.

Task 2 was to be completed by circling one of the four options offered, only one of which is the standard form of Future I, while the other three forms are dialectal and are features of the Prizren-Timok dialect.

Task 3 comprises sentences with past tenses of certain verbs on the basis of which the respondents should provide a future tense form of the verbs in the sentences which refer to future actions.

Task 4 contains only one sentence with no verb assigned, which should be completed entirely from the respondents' point of view, with any ideas they may have about their own future actions or plans as indicated by the prepositional phrase 'in ten years'. The respondents which took part in the research were 58 pupils of two elementary schools and 64 adults (122 respondents in total). There were 32 adult and 28 young respondents from the downtown zone of Niš, the town in the Prizren-Timok dialect region, and 32 adult and 30 young respondents from the suburban zone. 


\subsection{The data}

The analysis of the data has indicated that there is a certain correlation between Serbian language education and the frequency of the usage of non-dialectal form of Future I, which we here restrict to writing in Serbian. The calculations have demonstrated that $11,5 \%$ of young respondents and $30,3 \%$ of adults used futuroid in their answers, which is shown in Table 2:

RESPONDENT * FUTUROID Crosstabulation

\begin{tabular}{|c|c|c|c|c|c|}
\hline & & & & ROID & \\
\hline & & & USED BY & NOT USED BY & \\
\hline & & Count & 14 & 44 & 58 \\
\hline & & $\%$ within RESPONDENT & $24,1 \%$ & $75,9 \%$ & $100,0 \%$ \\
\hline & & $\%$ within FUTUROID & $27,5 \%$ & $62,0 \%$ & $47,5 \%$ \\
\hline & & $\%$ of Total & $11,5 \%$ & $36,1 \%$ & $47,5 \%$ \\
\hline & & Count & 37 & 27 & 64 \\
\hline & & $\%$ within RESPONDENT & $57,8 \%$ & $42,2 \%$ & $100,0 \%$ \\
\hline & & $\%$ within FUTUROID & $72,5 \%$ & $38,0 \%$ & $52,5 \%$ \\
\hline & & $\%$ of Total & $30,3 \%$ & $22,1 \%$ & $52,5 \%$ \\
\hline & & Count & 51 & 71 & 122 \\
\hline$T_{-1}$ & & $\%$ within RESPONDENT & $41,8 \%$ & $58,2 \%$ & $100,0 \%$ \\
\hline & & $\%$ within FUTUROID & $100,0 \%$ & $100,0 \%$ & $100,0 \%$ \\
\hline & & $\%$ of Total & $41,8 \%$ & $58,2 \%$ & $100,0 \%$ \\
\hline
\end{tabular}

Table 2. The frequency of futuroid usage in the questionnaire

The correspondence between the Serbian language teaching and the use of futuroid is expressed by Pearson correlation coefficient. The analysis suggests that the correlation between the instruction and futuroid use is average. Namely, the coefficient is $r=-.341$, which indicates the correlation may be confirmed $(p<0.01)$. The negative correlation substantiates the premise that the fewer Serbian language instruction classes the higher the percentage of the futuroid use frequency. 


\begin{tabular}{|ll|r|r|}
\hline & & RESPONDENT & FUTUROID \\
\hline \multirow{2}{*}{ RESPONDENT } & Pearson Correlation & 1 & $-.341^{* *}$ \\
& Sig. (1-tailed) & 122 &, 000 \\
& $\mathrm{~N}$ &,$- 341^{* *}$ & 122 \\
\cline { 2 - 3 } & Pearson Correlation &, 000 & 1 \\
FUTUROID & Sig. (1-tailed) & 122 & 122 \\
& $\mathrm{~N}$ & & \\
& &
\end{tabular}

Table 3. Pearson correlation coefficient

Speaking of the adult population, we find that the use of the dialectal futuroid is more frequent and more consistent with adults than with the population at school. First, the analysis of the results obtained in each of the tasks completed by the adult respondents points to the fact that in Task 2 one can note the most marked effect of futuroid in the adult speakers' vernacular. In Task 2 all of the four Future I structures are offered as a choice, one of which is the norm. Adult respondents most frequently chose futuroid in their Task 2 completion than in other three tasks. This finding signals that even when the normative Future I form is offered, it is either not recognized as such or is equated with its dialectal substitute, presumably due to the frequency with which futuroid is used in everyday language and all other communicative acts in speech and writing within the Prizren-Timok dialect region. Second, there are significant differences in the data obtained from the downtown and suburban adult population. The suburban population used futuroid more frequently than the downtown population, which verifies the assumption that dialectal features are more habitually preserved in the peripheral than the central zones of residential areas. Third, regarding the gender of both populations, the data show that 21 of 30 male respondents and 30 of 83 female respondents used futuroid in their answers. Further data collection would be required to address the issue of gender in dialectal use of futuroid, but in the present research the data suggest that male population is more inclined to use the dialectal form than the female population. 
GENDER * FUTUROID * RESPONDENT Crosstabulation

\begin{tabular}{|c|c|c|c|c|c|c|}
\hline & & & & FUTU & OID & \\
\hline & & & & USED BY & NOT USED BY & \\
\hline & & & Count & 9 & 10 & 19 \\
\hline & & & $\%$ within GENDER & $47,4 \%$ & $52,6 \%$ & $100,0 \%$ \\
\hline & & & $\%$ within FUTUROID & $64,3 \%$ & $22,7 \%$ & $32,8 \%$ \\
\hline & & & $\%$ of Total & $15,5 \%$ & $17,2 \%$ & $32,8 \%$ \\
\hline & & & Count & 5 & 34 & 39 \\
\hline PUPUS & & EFMAIF & $\%$ within GENDER & $12,8 \%$ & $87,2 \%$ & $100,0 \%$ \\
\hline & & & $\%$ within FUTUROID & $35,7 \%$ & $77,3 \%$ & $67,2 \%$ \\
\hline & & & $\%$ of Total & $8,6 \%$ & $58,6 \%$ & $67,2 \%$ \\
\hline & & & Count & 14 & 44 & 58 \\
\hline & Totol & & $\%$ within GENDER & $24,1 \%$ & $75,9 \%$ & $100,0 \%$ \\
\hline & & & $\%$ within FUTUROID & $100,0 \%$ & $100,0 \%$ & $100,0 \%$ \\
\hline & & & $\%$ of Total & $24,1 \%$ & $75,9 \%$ & $100,0 \%$ \\
\hline & & & Count & 12 & 8 & 20 \\
\hline & & & $\%$ within GENDER & $60,0 \%$ & $40,0 \%$ & $100,0 \%$ \\
\hline & & IVIRLL & $\%$ within FUTUROID & $32,4 \%$ & $29,6 \%$ & $31,2 \%$ \\
\hline & & & $\%$ of Total & $18,8 \%$ & $12,5 \%$ & $31,2 \%$ \\
\hline & & & Count & 25 & 19 & 44 \\
\hline ADUUTC & & ГГ & $\%$ within GENDER & $56,8 \%$ & $43,2 \%$ & $100,0 \%$ \\
\hline & & TLIVIALL & $\%$ within FUTUROID & $67,6 \%$ & $70,4 \%$ & $68,8 \%$ \\
\hline & & & $\%$ of Total & $39,1 \%$ & $29,7 \%$ & $68,8 \%$ \\
\hline & & & Count & 37 & 27 & 64 \\
\hline & & & $\%$ within POL & $57,8 \%$ & $42,2 \%$ & $100,0 \%$ \\
\hline & Tular & & $\%$ within FUTUROID & $100,0 \%$ & $100,0 \%$ & $100,0 \%$ \\
\hline & & & $\%$ of Total & $57,8 \%$ & $42,2 \%$ & $100,0 \%$ \\
\hline & & & Count & 21 & 18 & 39 \\
\hline & & & $\%$ within GENDER & $53,8 \%$ & $46,2 \%$ & $100,0 \%$ \\
\hline & & IVIRLL & $\%$ within FUTUROID & $41,2 \%$ & $25,4 \%$ & $32,0 \%$ \\
\hline Tatal & 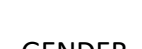 & & $\%$ of Total & $17,2 \%$ & $14,8 \%$ & $32,0 \%$ \\
\hline & & & Count & 30 & 53 & 83 \\
\hline & & FFMAIF & $\%$ within GENDER & $36,1 \%$ & $63,9 \%$ & $100,0 \%$ \\
\hline & & TLIVITLL & $\%$ within FUTUROID & $58,8 \%$ & $74,6 \%$ & $68,0 \%$ \\
\hline & & & $\%$ of Total & $24,6 \%$ & $43,4 \%$ & $68,0 \%$ \\
\hline
\end{tabular}

Table 4. Gender structure of the population 


\section{Conclusion}

Returning to the hypothesis posed at the beginning of this study, it is now possible to state that there exists a correlation between the use of dialectal futuroid in writing in Serbian and language instruction. As stated above, in the literature it is claimed that futuroid is a dialectal form of Future I tense and that it indicates that a process of Balkanization is underway in some dialects in Serbian, such as the Prizren-Timok dialect. In the questionnaire, the population of 122 respondents has offered the evidence that the instruction in Serbian language and literature serves to preserve the standard norm in the formation of Future I. Namely, the population still instructed at school is less inclined to use futuroid as their awareness of the standard form is still being raised. In terms of percentage, $57.8 \%$ of adult respondents and $24.1 \%$ of young respondents at school used the futuroid in their responses in the questionnaire. The most frequent futuroid responses are observable in the multiple-choice task, which suggests that the norm is gradually being overruled in the linguistic competence and performance of the Prizren-Timok dialect speakers.

To our knowledge, the study of morpho-syntax in the dialect has not been studied by the analysis of data obtained by interviewed speakers, while most of the research of dialects in Serbian is purely descriptive and does not focus on present-day variation. We believe that this research validates the importance of dialect studies with regard to language change. In our view, this small-scale study may offer evidence that language change in Serbian may be in progress as far as the Future I tense form is considered, or at least that the dialectal form is naturally-occurring alongside the standard in the performance of the Prizren-Timok dialect speakers. This may imply that the two options co-exist in an individual's competence, or that the norm is gradually and naturally abandoned in favor of the dialectal form, which is thus not recognized as non-standard. 


\section{References}

BARJAKTAREVIĆ, Danilo (1981) "Razvojni put konstrukcije za kazivanje budućnosti”, Naučni sastanak slavista u Vukove dane, 7/1, Beograd: Filološki fakultet, 323-330.

Brozović, Dalibor (1953) “O vrijednosti infinitiva i prezenta s veznikom da”, Jezik II/1, 13-18.

ĆORIĆ, Božo (2005) "Neke supstandardne pojave”, Naučni sastanak slavista u Vukove dane, 34/3, Beograd: Filološki fakultet, 279-287.

IVIĆ, Pavle (1985) Dijalektologija srpskohrvatskog jezika: uvod i štokavsko narečje, Novi Sad: Matica srpska.

JANJIĆ, Marina (2004) "Nastava padeža u školama na području prizrensko-timočkog dijalekta", Književnost i jezik, No. LI, Beograd: Čigoja štampa.

MEYERHOFF, Miriam (2006) Introducing Sociolinguistics, London \& New York: Routledge.

MILORADOVIĆ, Sofija (2015) "Srpski periferni govori - međujezički uticaji i balkanistički procesi", Gwary Dziś, Vol. 7, 71-82.

MRAzović, Pavica \& Zora Vukadinović (1990) Gramatika srpskohrvatskog jezika za strance, Novi Sad: Dobra vest.

MUTAVDžıć, Predrag (2013) Balkan i balkanologija: uvod u studije Jugoistočne Evrope, Beograd: Čigoja štampa.

PIPER, Predrag, Ivana ANTONIĆ, Vladislav Ružıć, Sreto TANASIĆ, Ljudmila PoPović \& Branko Tošović (2005) Sintaksa savremenog srpskog jezika, Beograd: Institut za srpski jezik SANU.

RADIĆ, Prvoslav (2011) Uvod u srbistiku, Beograd: Filološki fakultet.

SIMIć, Radoje (2009) "Normativni i upotrebni status futuroida ću/ćeš... + da + prezent", MSC Naučni sastanak slavista u Vukove dane, 38/1, Beograd: Filološki fakultet, 51-55.

SteVAnović, Mihailo (1986) Savremeni srpskohrvatski jezik, Beograd: Naučna knjiga.

TOPOLINJSKA, Zuzana (1994) "Infinitiv vs da-subjunktiv u formuli velle- futura", Govori prizrenskotimočke oblasti i susednih dijalekata, Niš: Filološki fakultet, Beograd: Institut za srpski jezik SANU, 149-160. 


\section{Appendix}

УПИТНИК

1. Пажљиво прочитајте следећи текст и упишите одговарајући облик речи (глагола) из заграде. (Read carefully the following text and fill in the adequate word (verb) form)

1. Сутра нећемо (иде) у школу.

(We will not (go) to school tomorrow.)

2. Прекосутра ће наши фудбалери (побеђују) репрезентацију Аустралије.

(In two days our football players (beat) the Australian team.)

3. (возим) пажљиво када се будем враћао из Софије. (drive, 1.p. sg.) when I return from Sofia.

4. За месец дана они ће (славе) Нову годину.

(In a month they will (celebrate) New Year.)

5. Сутра ћете (трче) на маратону.

(Tomorrow you will (run) the marathon.)

\section{2. У датим реченицама заокружите облик који бисте радије употребили.}

(In the following sentences circle the option you would preferably use.)

1. Ја ЋУ ДА УРАДИМ / ЋУ УРАДИМ / ЋУ УРАДИТИ / ЋЕ УРАДИМ наведенИ задатак прекосутра.

(I will do the assignment in two days.)

2. СУтра ЋЕМО ИГРАТИ / ЋЕ ИГРАМО / ЋЕ ДА ИГРАМО / ЋЕ ИГРАМО ИГРИЦе На рођендану.

(Tomorrow we will play games at the birthday party.)

3. Наша Деца ЋЕ ПОБЕДЕ / ЋЕ ДА ПОБЕДЕ / ЋЕ ПОБЕДИТИ / ЋЕ ДА ПОБЕДИТИ На такмичењу из српског језика.

(Our children will take the first place at the Serbian language competition.)

4. Ускоро ЋЕ ДА ДОЪЕ / ЋЕ ДОЪЕ / ЋЕ ДА ДОЋИ / ЋЕ ДОЋИ ДИректор И објаснитИ НаМ шта се десило.

(Soon the principal will come to explain what happened.)

5. ОНИ ЋЕ ЗАВОЛЕТИ / ЋЕ ДА ЗАВОЛЕ / ЋЕ ЗАВОЛУ / ЋЕ ЗАВОЛЕ новУ професорКУ. (They will start to like the new teacher.) 
3. Трансформишите текст тако што ћете подвучене које означавају прошлост преобликовати да означавају будућност.

(Transform the text by using the future tense forms instead of the past forms used in the sentences provided.)

Ти си показао заставу и ми смо скочили

Tи

са крова.

(You showed the flag and we jumped from the roof.)

Марија је пољубила Марка прекјуче.

(Marija kissed Marko two days ago.)
(I jumped yesterday.)
Марија Марка прекосутра.

(Marija Marko in two days.)

$\mathrm{Ja}$ сутра. са крова. the flag and we from the roof.)

(I___ jump tomorrow.)

4. Напишите реченицу о томе како видите себе за десет година (шта бисте радили). (Write a sentence about where you see yourself in ten years.)

За десет година ћу (In ten years I will .) 